\title{
Examining the Impact of Foreign Direct Investment (FDI) on Offshore CO2 in the Sub-Sahara
}

\author{
Ngonadi Josiah Chukwuma, Sun Huaping, Joy Okere, and Chuks Oguegbu
}

\begin{abstract}
The study focused on the origin and duration of the links between energy, $\mathrm{CO} 2$ production, and the economy in a sample of 12 selected sub-Saharan African countries. We used empirical tests in the annual data for the period 2008-2018. Special effects vary from country to country, in the long run, strong energy consumption (EC) and economy growth (EG) in many countries are associated with increased air pollution. The long-term results of the test provided economic growth, which led to short-term CO2 emissions in Benin, the Democratic Republic of Congo, Ghana, Nigeria and Senegal, this cannot be done without environmental impact. The link between $\mathrm{CO} 2$ emission and the economy has been shown in Gabon, Nigeria and Togo and shows that air pollution policies can affect their economy. In addition, bilateral links were found between shortterm economic growth and $\mathrm{CO} 2$ emissions in Nigeria and longterm relations with Congo and Gabon. greenhouse. $\mathrm{CO} 2$ in Benin, Ivory Coast, Nigeria, Senegal, South Africa and Togo.

Key words - FDI, CO2 emission, Sub Saharan Africa.
\end{abstract}

\section{INTRODUCTION}

Economic growth in sub-Saharan Africa has grown steadily, from $1.3 \%$ in 2016 to $2.4 \%$ in 2017 . It is being watched slowly in countries like Angola, Nigeria and South Africa of greatest wealth. Economic growth in South Africa is expected to fall by $3.2 \%$ in 2018 and $3.5 \%$ in 2019 , but growth is expected to slow [18]. To accelerate and maintain the global image, decision makers must invest in human resources, as described in [12] by reducing waste generation and increasing efficiency in the region. [23] argues that subSaharan politicians should have the right to face the challenges of the economic process. It is also important to ensure that the power to deliver economic development is strengthened. Growth and development cannot be achieved without strength. Energy is one of the most important variables for EG in sub-Saharan Africa and other parts of the world. [3] showed that access to electricity services is crucial for solving global and social problems such as poverty, inequality, food security, environmental problems, wellbeing and education. There is so much power that can be transformed in Africa. EC is vital for EG and access to cheap and reliable energy is an important part of the waste generation economy in the oil fields. Low carbon (inactive) energy consumption worldwide is necessary and no income is required [8].

According to UEMOA, FDI is defined as "the acquisition, creation or development of enterprises". It may also apply to other personal activities, to any other process in which one or more persons can simultaneously or as a result control or consolidate the finances of enterprises, agriculture, trade, finance or real estate, or to some extent-controlled companies. "Foreign direct investment is therefore part of the product structure of a foreign company that acquires shares in foreign companies [6]. Analysis of the relationship between foreign direct investment, growth and the environment, on the one hand, controversy on these harmful effects on the other: previous research into the environmental impact of direct investment and foreign trade relied heavily on "direct" equipment, while equipment " indirect "allows direct investment and foreign trade is economic reality [20]. Per the Kuznet environmental curve (EKC), the combination of GDP growth and emissions is non-linear and assumes that forming a typical U-shape [9]. This idea under the arc ends in a study conducted in 25 OECD countries, [14]. As part of this study, they observed an unstable ratio of U-shaped CO2 emissions per capita. Per capita and active GDP per capita in the years 1980-2010.

Although sub-Saharan Africa wants to develop economically, recent economic developments, energy needs and calls from foreign investors have raised significant concerns about pollution and in particular $\mathrm{CO} 2$ emissions [9]. [21] also confirmed that economic development must be a sin for everyone despite pollution. The impact of EG on the environment are most noticeable in countries where business is growing rapidly, causing $\mathrm{CO} 2$ emissions and affecting human health on a daily basis due to economic activities. It is also from [16] found that their policies and regulations have a major impact on industrialization, urbanization, irrigation, fertilizers, pesticides, and waste disposal, particularly in developing countries.

This study extended the current literature as follows. First, we measured the direct and indirect effects on direct investment, foreign trade and on $\mathrm{CO} 2$ emissions in certain

Published on February 23, 2020. 
sub-Saharan countries. Direct and indirect influence on the impact of foreign direct investment on $\mathrm{CO} 2$ emissions. Second, we use a backward quantitative panel to study the impact of FDI on the global distribution of $\mathrm{CO} 2$ emissions. Compared to the OLS method, quantitative feedback checks whether foreign direct investment and foreign trade systematically influence $\mathrm{CO} 2$ emissions at all quantitative levels, in particular in large or small quantities.

\section{LITERATURE REVIEW}

Although the theoretical results suggest a link between FDI, growth and the environment, empirical data are more useful and fall into four categories. The first creates a coherent link among EC and growth. The latter demands an increase in energy use due to EG. The second relationship between the two does not create a causal relationship among FDI and economic growth. The pollution and paradox hypothesis allow Kuznet's environmental curve to truely understand the relationship between FDI, growth and the environment and test two hypotheses.

First, with regard to the Pollution Haven Hypothesis (HHP), it should be noted that the political and regulatory considerations that allow companies to exhaust less severe environmental conditions eliminate environmental degradation. [1] tested their HHP and stated that foreign direct investment is not associated with environmental degradation in the case of the Gulf Cooperation Councils from 1980-2009. They argue that there is a system of nonlinear relations between direct foreigners. CO2 investments and emissions reflecting the lack of validation of HHP. [12] used a panel model to determine that FDI has a significant negative impact on $\mathrm{CO} 2$ emissions in the European Union from 1988 to 2009. [13] have already discussed these findings in priority environmental regulations for funding industries in European countries between 1998 and 2007. [5] confirmed, however, they observed a unilateral causal relationship between FDI and $\mathrm{CO} 2$ emissions. Here, 18 countries in Latin America are increasing $\mathrm{CO} 2$ emissions, due to the rise in foreign direct investment. [24] confirmed this result, indicating that there was an increase in the $\mathrm{CO} 2$ emissions of FDI in China from 1980 to 2009, similar to the Middle East.

In addition, foreign direct investment can encourage an increase or decrease in $\mathrm{CO} 2$ emissions. [22] showed that HHP was approved in the United States, France and England and rejected by Canada between 1970 and 2010. However, there was no statistically significant association between foreign investment. direct emissions and CO2. In fact, this is the case in Turkey, where [11], on the basis of the autonomous deferral model (ARD), could not identify a significant link among FDI and emission reduction of $\mathrm{CO} 2$ between 1970-2014, because of the small impact of FDI in GDP.
[16] studied the link among EG, CO2 emissions and EC in industrialized and emerging countries from 2001-2017 and showed a regression; the GMM model still showed that it did not work. EG has a direct impact on EC, but has a significant indirect impact on $\mathrm{CO} 2$ emissions in new countries and a significant indirect impact on energy consumption, but has a direct impact on $\mathrm{CO} 2$ emissions to new countries and regions. $\mathrm{CO} 2$ emissions from $\mathrm{EC}$ in all developing countries have an immediate impact on the development of industrialized and emerging countries. In developing countries in Asia, [10] examined the link between renewable energy use and CO2 emissions from the 1980-2014. They used the OLS and OLS dynamic estimates and found that they play a very important role in economic growth and energy consumption. With regard to $\mathrm{CO} 2$ emissions, he noted that EG and EC are lowering the quality of the environment. Regarding $\mathrm{CO} 2$ emission, [7] identified that it a significant direct impact on EG, population and energy intensity in regional and global $\mathrm{CO} 2$ emissions, while carbon dioxide emissions from renewable sources. down to around the world and in Europe, Asia and South Africa

In general, most previous studies on the effect of foreign trade on the environment and foreign trade used moderate regression. Of course, there are still aspects that need to be improved. First, several studies have shown the indirect effects of FDI and foreign trade on $\mathrm{CO} 2$ emissions, with economic growth being considered an important factor. Secondly, researches were unable to identify the broader environmental impacts of FDI and foreign trade, with $\mathrm{CO} 2$ emissions changes.

\section{METHODOLOGY}

The aim of this study is to study the impact of FDI on $\mathrm{CO} 2$ emissions in sub-Saharan Africa. Previous researches were conducted on the effect of EC and $\mathrm{CO} 2$ emissions and have shown a significant effect in EG, while [2], have noticed a significant effect of FDI on EG. We refer to these earlier studies to identify the most important parameters for the definition of our model.

Hansen formalized the General Momentum Model (GMM) in 1982. In general, GMM is generally used to evaluate vertical regression parameters in a panel data model and a single heterogeneity is unclear. For the ESL model, it is not compatible with a limited number of periods and a large number of transverse observations. While a typical amount of small panel data in the microeconomics is the case with many other consecutive GMM evaluators given in [2]. For this research, we adopted a level of distribution of GDP per capita, EG using the Arellano estimator and GMM Bond (1991). The following comparison shows an empirical impact on the impact of bilateral direct FDI, EC, CO2 emissions and capital on the EG of sub-Saharan Africa. 


$$
\begin{aligned}
\log (G D P P)_{h, t}= & \beta_{0}+\beta_{1} D C O 2_{h, s t}+\beta_{2} C O 2_{h, t} \\
& +\beta_{3} C O 2_{s, t}+\beta_{4} D(\log F D I)_{h, s t} \\
& +\beta_{5} \log (F D I)_{h, t}+\beta_{6} \log (F D I)_{s, t}+\varepsilon_{h, t}
\end{aligned}
$$

Where $\mathrm{h}$ is defined as the host countries, $\mathrm{s}$ defined source countries, $\mathrm{t}$ is defined as the time interval. $\beta_{0}$ represents the arbitrary constant, $\beta_{i}$ is the correlated coefficient in respect to various variable type. $\varepsilon_{h, t}$ is the errors term, $D C O 2$ is the difference $\mathrm{CO} 2$ emission, $\mathrm{CO}_{h}$ represents the emission of host countries, $F D I_{h}$ inflow of host countries, DFDI represents the difference of FDI on economic growth of the sub Saharan African countries.

Panel data were used in the analysis of 35 host countries and 40 countries of origin. Due to availability, data were collected for the period 2004-2015. All data were collected from [18]. Figure 1 shows investments in sub-Saharan Africa in 1980-2015.

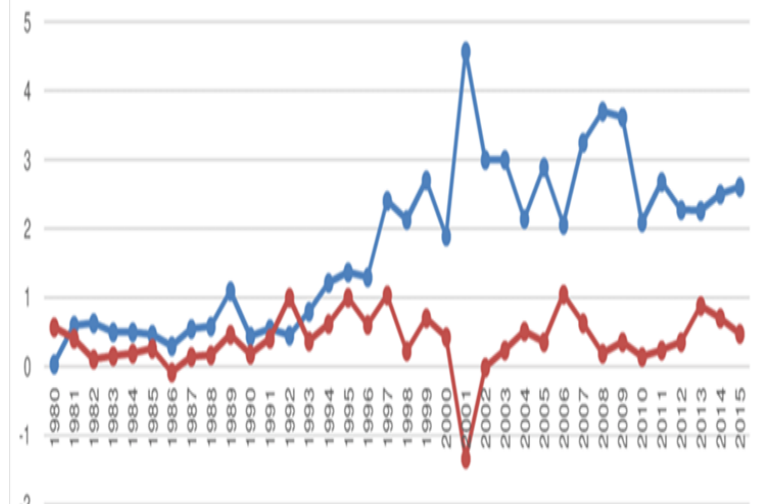

$\leftarrow$ Net inillows as percentage of GOP $\quad$-Net outlows a spercent of GOP

Fig. 1. FDI flows (\%GDP) in the Sub-Saharan Africa

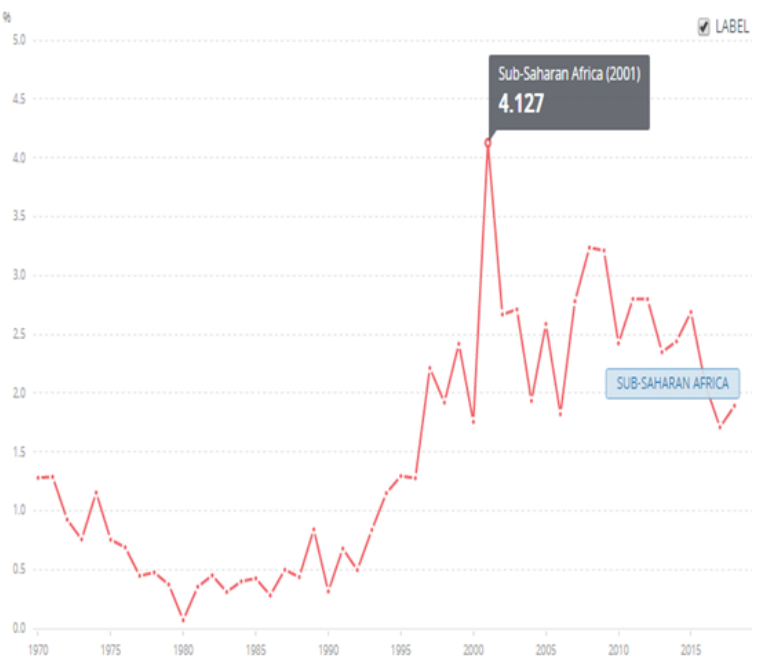

Fig. 2. FDI (\%GDP) of Sub Saharan AFRICA from1970-2018
From Figure 2 above we can observe that from 1971 to 2001 the FDI of the Sub Saharan Africa has an increasing trend which can be explained by the adoption of policies that attracted foreign invested. But from 2001 to 2018 there is a net decrease in foreign investment due to many factors but in this study, we mainly focus on the emission of $\mathrm{CO} 2$

\section{EMPIRICAL ANALYSIS AND RESULT}

We examined the impact of several variables, such as differences in $\mathrm{CO} 2$ emissions (CO2D), $\mathrm{CO} 2$ emissions in recipient countries $(\mathrm{CO} 2 \mathrm{~h})$ and countries of origin $(\mathrm{CO} 2 \mathrm{o})$, differences in FDI flows (DFDIf), FDI inflows in receiving countries (FDIh) and outgoing FDI in countries of origin (oFDI) for the EG of host countries in Sub-Saharan Africa (GDPPh) to 36 host countries and 40 countries of origin using the $\mathrm{MCO}$ regression, permanent and random effect, as well as the generalized torque method (GMM), which takes into account the levels of EG delay using the GMM estimator of [5]

The following table 1 shows that the advantages and disadvantages of the difference between $\mathrm{CO} 2$ emissions at $\mathrm{EC}$ are favorable countries. Concern about fairness indicates that the $\mathrm{CO} 2$ emissions of beneficiary countries have a negative impact on economic growth in host countries, so that the government may need more care. with regard to medical care. - environmental pollution and cancer. 
TABLE 1 IMPACT OF VARIOUS VARIABLE ON EG IN THE SUB SAHARAN AFRICA

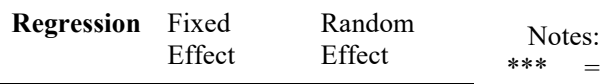

\begin{tabular}{|c|c|c|c|}
\hline \multicolumn{4}{|l|}{$\begin{array}{l}\text { Dependent } \\
\text { variable: EG }\end{array}$} \\
\hline \multirow[t]{2}{*}{ DCO2 } & $0.009 * * *$ & $0.013 * * *$ & $0.015 * * *$ \\
\hline & $(0.002)$ & $(0.004)$ & $(0.002)$ \\
\hline \multirow[t]{2}{*}{ CO2hs } & $-0.020 * *$ & $0.013 * * *$ & 0.005 \\
\hline & $(0.004)$ & $(0.004)$ & $(0.005)$ \\
\hline \multirow[t]{2}{*}{$\mathrm{CO} 20$} & -0.003 & -0.004 & $-0.008 * *$ \\
\hline & $(0.003)$ & $(0.005)$ & $(0.003)$ \\
\hline \multirow[t]{2}{*}{ DFDIf } & $0.021 * * *$ & $0.005^{*}$ & $0.008 * * *$ \\
\hline & $(0.004)$ & $(0.003)$ & $(0.002)$ \\
\hline \multirow[t]{2}{*}{ FDIh } & $0.020 * * *$ & $0.009 * * *$ & $0.017 * * *$ \\
\hline & $(0.003)$ & $(0.003)$ & $(0.003)$ \\
\hline \multirow[t]{2}{*}{ oFDI } & $0.018 * * *$ & 0.004 & $0.011 * * *$ \\
\hline & $(0.005)$ & $(0.003)$ & $(0.002)$ \\
\hline \multirow[t]{2}{*}{ Dfd } & -0.001 & $0.001 * * *$ & $0.001 * * *$ \\
\hline & $(0.001)$ & $(0.001)$ & $(0.001)$ \\
\hline \multirow[t]{2}{*}{ Fdhe } & $-0.004 * * *$ & $-0.001 * * *$ & $-0.002 * * *$ \\
\hline & $(0.001)$ & $(0.001)$ & $(0.001)$ \\
\hline \multirow[t]{2}{*}{ Fdho } & -0.001 & -0.001 & 0.001 \\
\hline & $(0.001)$ & $(0.001)$ & $(0.001)$ \\
\hline \multirow[t]{2}{*}{ Constant } & $-0.376^{* * *}$ & $-4.713 * * *$ & $-1.761 * * *$ \\
\hline & $(0.129)$ & $(0.532)$ & $(0.207)$ \\
\hline Observations & 1,732 & 1,732 & 1,732 \\
\hline R-squared & 0.978 & 0.790 & \\
\hline Hausman test & & 0.000 & \\
\hline
\end{tabular}

Significance at 0.01 level, $* *=$ Significance at 0.05 level and, $*=$ Significance at 0.1 level.

The impact effects show a positive correlation with the $\mathrm{CO} 2$ emissions of the countries, but are not a significant factor for the $\mathrm{CO} 2$ emissions of the countries that benefit from the national economic benefits. a blessing. The CO2 emissions of the countries concerned have an impact on the overall use of the model, but not only have a significant impact on the countries' ECs, but have little effect on emissions and long-term effects. The national economy is being embraced. All models show that the growth and spread of FDI in countries that benefit from the national economy and the effects have a positive and significant effect. good and important. FDI in producing countries.
TABLE 2 IMPACT OF VARIOUS VARIABLE ON THE EG OF SUB SAHARAN AFRICAN COUNTRIES (GMM)

\begin{tabular}{|c|c|c|c|c|c|}
\hline $\begin{array}{l}\text { Dependent variable: } \\
\text { EG }\end{array}$ & (1) & (2) & (3) & (4) & (5) \\
\hline \multirow[t]{2}{*}{ logGDPPCht-1 } & 0.895 & 0.903 & $0.804 * *$ & $0.853 * *$ & \\
\hline & )$^{(0.005}$ & $\begin{array}{l}(0.005 \\
)^{2}\end{array}$ & $(0.017)$ & $(0.006)$ & $(0.021)$ \\
\hline \multirow[t]{2}{*}{$\mathrm{DCO} 2$} & & $\begin{array}{l}-0.00 \\
8 * * *\end{array}$ & & & $\begin{array}{l}0.007^{*} \\
* *\end{array}$ \\
\hline & & )$^{(0.001}$ & & & $(0.002)$ \\
\hline \multirow[t]{2}{*}{$\mathrm{CO} 2 \mathrm{~h}$} & & $\begin{array}{l}0.021 \\
* * *\end{array}$ & & & $\begin{array}{l}0.013 * \\
* *\end{array}$ \\
\hline & & )$^{(0.001}$ & & & $(0.003)$ \\
\hline \multirow[t]{2}{*}{$\mathrm{CO} 2 \mathrm{o}$} & & $\begin{array}{l}0.012 \\
* * *\end{array}$ & & & -0.001 \\
\hline & & )$^{(0.001}$ & & & $(0.003)$ \\
\hline \multirow[t]{2}{*}{ DFDIf } & & & 0.001 & & $\begin{array}{l}0.003 * \\
*\end{array}$ \\
\hline & & & $(0.003)$ & & $(0.002)$ \\
\hline \multirow[t]{2}{*}{ oFDI } & & & $\begin{array}{l}0.009 * * \\
*\end{array}$ & & $\begin{array}{l}0.004 * \\
*\end{array}$ \\
\hline & & & $(0.003)$ & & $(0.002)$ \\
\hline \multirow[t]{2}{*}{ FDIo } & & & $\begin{array}{l}0.015^{* *} \\
*\end{array}$ & & $\begin{array}{l}0.006^{*} \\
* *\end{array}$ \\
\hline & & & $(0.003)$ & & $(0.002)$ \\
\hline \multirow[t]{2}{*}{ Dfd } & $\begin{array}{l}0.000 \\
* * *\end{array}$ & $\begin{array}{l}0.001 \\
* * *\end{array}$ & 0.001 & $\begin{array}{l}0.001 * * \\
*\end{array}$ & $\begin{array}{l}0.001 * \\
* *\end{array}$ \\
\hline & )$^{(0.001}$ & )$^{(0.001}$ & $(0.001)$ & $(0.001)$ & $(0.001)$ \\
\hline \multirow[t]{2}{*}{ Fdhe } & $\begin{array}{l}-0.00 \\
2 * * *\end{array}$ & $\begin{array}{l}-0.00 \\
1 * * *\end{array}$ & $\begin{array}{l}-0.001 * \\
*\end{array}$ & $\begin{array}{l}-0.001 \\
* * *\end{array}$ & $\begin{array}{l}-0.001 \\
* * *\end{array}$ \\
\hline & )$^{(0.002}$ & )$^{(0.002}$ & $(0.001)$ & $(0.001)$ & $(0.001)$ \\
\hline \multirow[t]{2}{*}{ Fdsc } & $\begin{array}{l}-0.00 \\
2\end{array}$ & $\begin{array}{l}-0.00 \\
2\end{array}$ & -0.001 & $\begin{array}{l}-0.001 \\
* * *\end{array}$ & $\begin{array}{l}-0.001 \\
* * *\end{array}$ \\
\hline & )$^{(0.001}$ & )$^{(0.001}$ & $(0.001)$ & $(0.001)$ & $(0.001)$ \\
\hline Observations & 6,423 & 6,598 & 972 & 6,568 & 961 \\
\hline
\end{tabular}

The economic growth of the country benefits from the recovery and the negative effects and long-term 
sustainability shows a close relationship, but has no significant impact on the national economy.

The table below, summarizes the result when taking into account the impact of EC, $\mathrm{CO} 2$ emissions, FDI and capital on the EG of the recipient countries in the Sub Saharan Africa using regression, fixed power and GMM difference. The most important independent variable is GDP per capita. Inhabitant, which required EG.

The difference in $\mathrm{CO} 2$ shows a positive and significant effect on economic growth in any model except GMM, due to its negative influence on the economy. The $\mathrm{CO} 2$ outcome of all variables except the GMM model show that economic growth is caused by differences in carbon dioxide differences. Carbon dioxide production in the host country has shown a positive and significant link with EG all over, except for the recession, due to renewable behavior is influenced. bad in the economy. Recognition of carbon dioxide emissions can be found in all but examples of stimulating economies due to an increase in carbon production by two. baggage in the host country. $\mathrm{CO} 2$ production in this country follows only a positive and important relationship with GMM's personal economic growth, but in all other instances the effect is negative but negative. in economics. The variation in FDI shows a positive and significant correlation with EG, but not for individual GMM, due to the fact that it has a positive effect, however it does not. economic growth has increased significantly. The result of the difference in FDI shows that an increase in FDI drives the economy.

\section{v. CONCLUSION AND RECOMMENDATION}

The purpose of the conducted research was to evaluate the impact of external $\mathrm{CO} 2$ emissions from emissions. All models show that the difference between $\mathrm{CO} 2$ positively influence the national economy. The removal of the signs indicates that $\mathrm{CO} 2$ emission will have a detrimental effect on the growth of the host country, and the situation in question is showing positive and important consequences in the countries involved. On the other hand, withdrawal effect shows a close relationship between $\mathrm{CO} 2$ emissions from recipient countries, but they do not show the significant impact of $\mathrm{CO} 2$ emissions from developing countries on the economy of developing countries. Domestic CO2 emissions are negatively related in all models, but they did not affect the EG of the host countries, but in respect of recession associated with long-term results are not important to them to grow the country's economy. All examples show that most FDI in the host country has a positive and significant impact on the country's EG and that the country's FDI originates, there is a positive and positive effect on economic growth. countries experiencing the recession and its mitigating effects, and in the context of the organization, showing a positive but not significant impact on sub-Saharan Africa's economic well-being in 2004 and 2015. The results reflect the heterogeneity of the effects of foreign direct investment $\mathrm{CO} 2$ emissions, impact of foreign direct investment on negative and significant $\mathrm{CO} 2$ emissions. Our results also confirm that there is an EKC hypothesis in the poorest countries. However, the environmental impact of FDI depends on the indirect and adopted effects. The empirical results presented above have the following political implications.

First, since FDI can be a channel for green technology, it is necessary to develop and apply stricter environmental standards for low emissions to attract net foreign direct investment. Small and medium-sized countries should optimize the distribution structure of FDI and encourage the quality of FDI rules rather than quantitative methods.

Secondly, it is important to ensure that the use of environmentally friendly technologies in export-oriented industries improves the structure of small and medium-sized emissions trading. Sub-Saharan countries can offer different incentives, such as tax breaks or whole-industry exemptions, to encourage producers to switch to environmentallyfriendly industries. It is again estimated that exports of environmentally harmful products to this area will be limited or prohibited.

Our study has its limitations, since the characteristics of the potential spatial relationship between neighboring countries in sub-Saharan Africa, other analyzes can investigate the spatial effect of FDI, foreign trade and $\mathrm{CO} 2$ emissions.

\section{REFERENCES}

[1] Al-Mulali, U., Tang, C. F. (2013). Investigating the validity of pollution haven hypothesis in the gulf cooperation council (GCC) countries. Energy Policy, vol.60, p.813-819. DOI.org/10.1016/j.enpol.2013.05.055.

[2] Bashir Muhammad and Sher Khan (2019), Effect of bilateral FDI, energy consumption, $\mathrm{CO} 2$ emission and capital on economic growth of Asia countries. Energy Reports Volume 5 p1305-1315, November 2019. https://doi.org/10.1016/j.egyr.2019.09.004

[3] Bazilian M, Nussbaumer P, Rogner H-H, Brew-Hammond A, Foster V, Pachauri S et al (2012) Energy access scenarios to 2030 for the power sector in sub-Saharan Africa. Util Policy 20(1):1-16. https://doi.org/10.1016/j.jup.2011.11.002.

[4] Bekhet HA, Matar A, Yasmin T (2017) CO2 emissions, energy consumption, economic growth, and financial development in GCC countries: Dynamic simultaneous equation models. Renew Sust Energ Rev 70:117-132. https://doi.org/10.1016/j.rser.2016.11.089

[5] Blanco, L., Gonzalez, F., Ruiz I. (2013). The impact of FDI on CO2 emissions in Latin America. Oxford Development Studies, vol.41, $\mathrm{n}^{\circ} 1$, p.104-121. DOI. 10.1080/13600818.2012.732055

[6] Dago, G. J. (2010). L'économie politique de l'investissement direct étranger (IDE) et le changement institutionnel : le cas de la Côte d'Ivoire. Thèse de doctorat en Sciences Economiques, Université Picardie Jules Verne d'Amiens (France).

[7] Dong et al., 2019, Dong K., Dong X., Dong C. Determinants of the global and regional co2 emissions: What causes what and where? Appl. Econ. (2019), pp. 1-14

[8] Fankhauser S, Jotzo F (2018) Economic growth and development with low-carbon energy. Wiley Interdiscip Rev Clim Chang 9(1):e495. https://doi.org/10.1002/wcc.495 
[9] G. M. Grossman and A. B. Krueger, "Economic growth and the environment," The Quarterly Journal of Economics, vol. 110, no. 2, pp. 353-377, 1995.

[10] Hasnisah et al., 2019, Hasnisah A., Azlina A.A., Taib C.M.I.C. The impact of renewable energy consumption on Carbon dioxide emissions: Empirical evidence from developing countries in asia Int. J. Energy Econ. Policy, 9 (3) (2019), pp. 135-143

[11] Kizilkaya O. (2017). The impact of economic growth and foreign direct investment on $\mathrm{CO} 2$ emissions: the case of Turkey. Turkish Economic Review, vol.4, n 1 , p.106-118.

[12] Lee, J. W., Brahmasrene, T. (2013). Investigating the influence of tourism on economic growth and carbon emissions: evidence from panel analysis of the European Union. Tourism Management, vol.38, p.69-76.

[13] Leiter, A. M., Parolini, A., Winner, H. (2011). Environmental regulation and investment: evidence from European industry data. Ecological Economics, vol.70, nº 4 p.759-770. DOI.org/10.1016/j.ecolecon.2010.11.013.

[14] M. B. Jebli, S. B. Youssef, and I. Ozturk, "Testing environmental Kuznets curve hypothesis: The role of renewable and non-renewable energy consumption and trade in OECD countries," Ecological Indicators, vol. 60, pp. 824-831, 2016.

[15] Maxim Tano Assi (2018), Do foreign direct investment in ivory coast increase co2 emissions? Journal of Business, Economics and Finance- V.7-ISS.4-2018(4)-p.346-358.DOI: 10.17261/Pressacademia.2018.995.

[16] Muhammad, 2019.Muhammad B. Energy consumption, co2 emissions and economic growth in developed, emerging and middle east and north africa countries Energy, 179 (2019), pp. 232-245

[17] Ndambiri H, Ritho C, Ng'ang'a S, Kubowon P, Mairura F, Nyangweso P et al (2012) Determinants of economic growth in subSaharan Africa: a panel data approach. International Journal of Economics and Management Sciences 2(2):18-24.

[18] World Bank (2018b) Global economic prospects: sub-Saharan Africa. Retrieved from https:/www.worldbank.org/en/region/afr/brief/global-economicprospects-sub-saharan-africa-2018. Accessed 22 Dec 2018.

[19] Y. Hao and Y.-M. Liu, "Has the development of FDI and foreign trade contributed to China's $\mathrm{CO} 2$ emissions? An empirical study with provincial panel data," Natural Hazards, vol. 76, no. 2, pp. 10791091, 2015.

[20] Y. Liu, Y. Hao, and Y. Gao, "The environmental consequences of domestic and foreign investment: Evidence from China," Energy Policy, vol. 108, pp. 271-280, 2017.

[21] Zaman K, Moemen M A-e (2017) Energy consumption, carbon dioxide emissions and economic development: evaluating alternative and plausible environmental hypothesis for sustainable growth. Renew Sust Energ Rev 74:1119-1130.

[22] Zeren, F. (2015). The impact of foreign direct investment on $\mathrm{CO} 2$ emission: pollution halo or pollution haven hypothesis? Journal of Yasar University, 10(37), p.6442-6448.

[23] Zeufack A (2018) Growth in sub-Saharan Africa is slower than expected. Retrieved from https://www.worldbank.org/en/news/pressrelease/2018/10/03/growth-in-sub-saharan-africa-is-slower-thanexpected. Accessed 22 Dec 2018.

[24] Zhang, C., Zhou, X. (2016). Does foreign direct investment lead to lower $\mathrm{CO} 2$ emissions? Evidence from a regional analysis in China. Renewable and Sustainable Energy Reviews, vol.58, p.943-952. 